\title{
PELUANG USAHA INDUSTRI PARIWISATA DI JAKARTA SELATAN
}

\author{
Dyah Budiastuti'; Andri²; ${ }^{1}$ gus ${ }^{3}$ \\ 1,2,3 Jurusan Manajemen, Fakultas Ekonomi dan Bisnis, Universitas Bina Nusantara, \\ Jln. K.H. Syahdan No. 9, Palmerah, Jakarta Barat 11480 \\ dyanto@binus.ac.id
}

\begin{abstract}
Well-managed tourism will be capable of contributing to the increase in local revenues and be capable to attract investors and open up jobs. Lack of socialization of the tourism potential in a region becomes an obstacle for investors to get involved in it. This research aims to identify the business opportunities of tourism industry and potential of tourism industry in South Jakarta. Data are obtained from the Suku Dinas Pariwisata Jakarta Selatan and analyzed with descriptive statistical methods. The results show that Setiabudi District has an opportunity for hospitality business; Mampang Prapatan, Pasar Minggu, and Kebayoran Baru District have opportunities for recreation and entertainment business.
\end{abstract}

Keywords: business opportunity, potency, tourism industry

\begin{abstract}
ABSTRAK
Pariwisata yang terkelola dengan baik akan mampu memberikan kontribusi bagi peningkatan Pendapatan Asli Daerah (PAD) dan mampu menarik investor serta membuka lapangan pekerjaan. Kurangnya sosialisasi akan potensi pariwisata di suatu daerah menjadi penghambat bagi investor untuk terlibat di dalamnya. Penelitian ini bertujuan untuk mengetahui peluang usaha industri pariwisata serta potensi pariwisata yang ada di Jakarta Selatan. Data diperoleh dari Suku Dinas Pariwisata Jakarta Selatan dan dianalisis dengan metode statistik deskriptif. Hasil penelitian menunjukkan Kecamatan Setiabudi memiliki peluang untuk usaha perhotelan, Kecamatan Mampang Prapatan, Pasar Minggu, dan Kebayoran Baru memiliki peluang untuk usaha rekreasi dan hiburan.
\end{abstract}

Kata kunci: peluang usaha, potensi, industri pariwisata 


\section{PENDAHULUAN}

Dewasa ini, banyak negara di dunia sedang berbenah diri untuk menghadapi globalisasi dan perdagangan bebas yang akan diaplikasikan dalam beberapa tahun ke depan seperti AFTA, APEC, dan GATT-WTO. Hal ini akan membawa dampak sosial, ekonomi terhadap suatu negara karena di era tersebut persaingan antarkota besar, baik di tingkat regional maupun internasional akan semakin tajam. Perdagangan bebas dan era globalisasi tersebut akan menjadi tantangan juga bagi DKI Jakarta sebagai ibukota negara yang berfungsi sebagai pusat pemerintahan, perdagangan, pariwisata, dan investasi diharapkan mampu memainkan peran di berbagai sektor dengan memanfaatkan peluang serta potensi yang ada, dan pada gilirannya nanti akan memberikan kontribusi yang lebih besar bagi pembangunan kota Jakarta.

Salah satu sektor industri yang diharapkan mampu menjawab segala tantangan ini adalah sektor pariwisata karena sektor ini dapat memberikan kontribusi bagi peningkatan Pendapatan Asli Daerah (PAD) dan meningkatkan jumlah peluang usaha yang dapat dimasuki oleh investor asing, memperluas dan melakukan pemerataan kesempatan usaha serta mendorong laju pertumbuhan dan pembangunan di Provinsi DKI Jakarta.

Pertumbuhan industri pariwisata merupakan salah satu faktor penanda utama yang terkait dengan peningkatan kegiatan perekonomian dan pembangunan tata ruang fisik kawasan-kawasan di wilayah tersebut. Industri pariwisata yang berkembang dengan pesat di satu sisi dapat memberikan dampak positif dalam hal penyediaan layanan kepariwisataan dan peningkatan kesejahteraan masyarakat. Namun di sisi lain, industri pariwisata yang tumbuh secara alami sekedar mengikuti trend pasar juga dapat mendorong timbulnya dampak negatif seperti ketidaksesuaian fungsi ruang dan berbagai gangguan lingkungan. Karenanya, perlu ada arahan dan pengendalian pertumbuhan yang tepat disesuaikan dengan daya dukung kota.

Khususnya di Jakarta Selatan, pemerintah kota telah menargetkan peningkatan Pendapatan Asli Daerah (PAD) sebesar 20\% (Rp 500 miliar) dari sektor pariwisata. Tahun lalu sektor pariwisata menyumbang PAD sebesar Rp 40 miliar. Target PAD sebesar ini berasal dari 1.200 tempat pariwisata, yang meliputi hiburan malam, mandi uap, bioskop, restoran, dan hotel. Bagi Suku Dinas Pariwisata Jakarta Selatan yang bertanggung jawab langsung pada pertumbuhan pariwisata di wilayahnya, naiknya target PAD sebesar $20 \%$ yang bersumber dari industri pariwisata merupakan tantangan yang tidak mudah. Mengandalkan dana pengembangan dan pengelolaan yang bersumber dari Dinas Pariwisata saja tidaklah mungkin. Oleh karena itu, perlu dilakukan usaha-usaha dengan menggandeng investor. Di sisi lain, investor juga perlu mempelajari secara mendalam kemungkinan-kemungkinan peluang usaha, khususnya di industri pariwisata yang ditawarkan pemerintah kota Jakarta Selatan.

Mengenali peluang usaha tergantung dari daya imajinasi seseorang yang membuatnya mampu melihat sesuatu dari sisi positif. Menurut Jackie Ambadar, $d k k$ (2003:53), ada 2 format yang mungkin dilakukan seseorang dalam usahanya mengenali peluang, yaitu (1) See-do-get, di mana seseorang yang melihat (see) peluang untuk dilaksanakan (do) menjadi bisnis (get) yang menguntungkan (profit / sukses); dan (2) Do-see-get, di mana seseorang terlibat (do) dalam suatu bisnis, kemudian menemukan (see) peluang bisnis baru (get) yang menguntungkan. Peluang akan muncul menjadi "peluang emas" (prospektif) bila mengandung unsur-unsur seperti sedang dibutuhkan oleh pasar, memecahkan kesulitan atau masalah yang sedang dihadapi pasar, menyempurnakan yang sebelumnya, benar-benar ada dan memiliki nilai tambah, temuan yang orisinil (inovatif), memberi keuntungan yang nyata, ada unsur yang dibanggakan, dan dapat diwujudkan.

Mengetahui peluang usaha dan potensi pariwisata di Jakarta Selatan merupakan satu hal yang tidak hanya penting dan banyak menentukan keberhasilan bagi Suku Dinas Pariwisata Jakarta Selatan karena dapat meningkatkan pendapatan asli daerah (PAD) dan sebagai sumber investasi serta ujung 
tombak peningkatan daya tarik pariwisata DKI Jakarta, namun juga penting bagi investor yang akan menanamkan modalnya. Untuk itulah perlu diteliti dan dianalisis peluang usaha apa sajakah di sektor pariwisata yang berpotensi untuk dikembangkan di wilayah Jakarta Selatan.

Rumusan masalah penelitian ini adalah (1) Bagaimana peta kondisi industri pariwisata di Jakarta Selatan saat ini?; (2) Peluang usaha industri pariwisata apakah di Jakarta Selatan yang berpotensi untuk dikembangkan oleh investor?; dan (3) Bagaimanakah sebaiknya investor menyikapi peluang usaha industri pariwisata di Jakarta Selatan tersebut?. Sedangkan tujuan penelitiannya adalah untuk (1) Mempelajari peta kondisi industri pariwisata di Jakarta Selatan (T-1); (2) Mengetahui peluang usaha industri pariwisata di Jakarta Selatan yang berpotensi untuk dikembangkan (T-2), memberikan usulan rekomendasi bagi investor untuk berinvestasi pada industri pariwisata di Jakarta Selatan (T-3).

\section{METODE PENELITIAN}

Penelitian ini merupakan penelitian deskriptif yang dimaksudkan untuk memberikan gambaran tentang peta kondisi pariwisata di Jakarta Selatan dan peluang-peluang usaha yang memungkinkan untuk dikembangkan, dengan unit analisis Suku Dinas Pariwisata Jakarta Selatan. Operasionalisasi varibael dalam penelitian ini dapat dilihat pada tabel 1 berikut).

Tabel 1 Operasionalisasi Variabel

\begin{tabular}{|c|c|c|c|}
\hline $\begin{array}{c}\text { Variabel / } \\
\text { Subvariabel }\end{array}$ & $\begin{array}{c}\text { Konsep Variabel \& } \\
\text { Subvariabel }\end{array}$ & Indikator & Ukuran \\
\hline $\begin{array}{l}\text { Kondisi industri } \\
\text { Pariwisata }\end{array}$ & $\begin{array}{l}\text { Peta kondisi industri pariwisata } \\
\text { yang ada saat ini }\end{array}$ & $\begin{array}{l}\text { Produk (product) } \\
\text { Pariwisata }\end{array}$ & $\begin{array}{l}\text { Berkembang atau tidak } \\
\text { berkembang }\end{array}$ \\
\hline Potensi Pariwisata & $\begin{array}{l}\text { Daya tarik yang terkandung pada } \\
\text { suatu daerah untuk dikembangkan } \\
\text { menjadi suatu objek wisata }\end{array}$ & $\begin{array}{l}\text { Produk (product) } \\
\text { Pariwisata }\end{array}$ & $\begin{array}{l}\text { Menarik atau tidak menarik } \\
\text { bagi investor }\end{array}$ \\
\hline Peluang industri & $\begin{array}{l}\text { Suatu keadaan dimana terdapat } \\
\text { kesempatan untuk melakukan } \\
\text { kegiatan industri }\end{array}$ & $\begin{array}{l}\text { Potensi industri } \\
\text { pariwisata pada tiap } \\
\text { Kecamatan }\end{array}$ & $\begin{array}{l}\text { Berpeluang atau tidak } \\
\text { berpeluang }\end{array}$ \\
\hline
\end{tabular}

Data dianalisis dengan teknik sebagai berikut:

Tabel 2 Teknik Analisis

\begin{tabular}{ccc}
\hline Tujuan Penelitian & Jenis Penelitian & Metode Analisis \\
\hline$(\mathrm{T}-1)$ & Deskriptif & Statistik Deskriptif \\
$(\mathrm{T}-2)$ & Deskriptif & Statistik Deskriptif \\
$(\mathrm{T}-3)$ & Deskriptif & Statistik Deskriptif \\
\hline
\end{tabular}




\section{HASIL DAN PEMBAHASAN}

Suku Dinas Pariwisata Provinsi DKI Jakarta Selatan mempunyai tugas membina dan mengembangkan kepariwisataan di Kotamadya sesuai dengan kebijakan teknis yang ditetapkan oleh Kepala Dinas dan kebijakan operasional yang ditetapkan oleh Walikotamadya, sedangkan fungsinya adalah (1) Pelaksanaan pembinaan dan pengembangan terhadap usaha sarana pariwisata, objek dan daya tarik wisata di wilayahnya; (2) Pelaksanaan penyuluhan kepariwisataan kepada masyarakat; (3) Pemberian petunjuk teknis tentang kegiatan usaha sarana pariwisata, objek dan daya tarik wisata; (4) Pemberian perizinan dan atau rekomendasi terhadap kegiatan dan usaha pariwisata; (5) Pelaksanaan kegiatan ketatausahaan; (6) Pelaksanaan pemantauan, evaluasi, pengendalian dan melaporkan kegiatan kepada Kepala Dinas dan Walikota Administrasi di wilayah yang bersangkutan; (7) Pelaksanaan tugas-tugas lain yang diberikan oleh Kepala Dinas.

\section{Peta Kondisi Industri Pariwisata di Jakarta Selatan}

Wilayah Jakarta Selatan terkenal sebagai surganya gaya hidup metropolitan. Berbagai sarana/lokasi rekreasi dan hiburan tersebar di hampir seluruh Kecamatan, terutama di Kecamatan Kebayoran Baru. Peta kondisi industri pariwisata di wilayah ini, dapat dilihat pada diagram berikut:

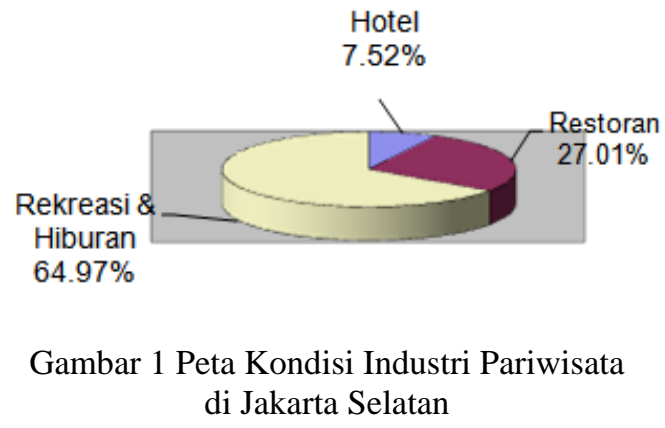

Industri rekreasi dan hiburan mencatat angka 64,97\% dari jumlah seluruh industri pariwisata yang tercatat di Jakarta selatan. Prosentase terbesar kedua adalah restoran (27,01\%), sementara yang terkecil adalah hotel (7,52\%). Di bawah ini adalah tabel yang menunjukkan jumlah industri pariwisata per Kecamatan di Jakarta Selatan pada tahun 2008 (Table 3).

Tabel 3 Jumlah Industri Pariwisata per Kecamatan

\begin{tabular}{clccc}
\hline No & Kecamatan & Hotel & Restoran & $\begin{array}{c}\text { Rekreasi } \\
\text { \& Hiburan }\end{array}$ \\
\hline 1 & Kebayoran Baru & 14 & 33 & 229 \\
2 & Kebayoran Lama & 2 & 30 & 60 \\
3 & Setiabudi & 13 & 26 & 70 \\
4 & Mampang Prapatan & 10 & 18 & 39 \\
5 & Tebet & 4 & 14 & 25 \\
6 & Pancoran & 1 & 16 & 21 \\
7 & Pasar Minggu & 3 & 13 & 20 \\
8 & Cilandak & 8 & 38 & 42 \\
9 & Jagakarsa & 0 & 11 & 0 \\
10 & Pesanggrahan & 4 & 13 & 4 \\
\hline \multicolumn{2}{c}{ Total (unit) } & 59 & 212 & 510 \\
\hline
\end{tabular}

Sumber: Suku Dinas Pariwisata Jakarta Selatan 
Industri rekreasi dan hiburan terbagi atas berbagai jenis usaha seperti terlihat pada tabel berikut:

Tabel 4 Jenis Usaha Rekreasi dan Hiburan

\begin{tabular}{clcclc}
\hline No & Jenis Usaha & Jumlah & No & Jenis Usaha & Jumlah \\
\hline 1 & Musik Hidup & 83 & 10 & Taman Rekreasi & 8 \\
2 & Karaoke & 75 & 11 & Arena Latihan Golf & 4 \\
3 & Salon & 75 & 12 & Gelanggang Bola Gelinding & 4 \\
4 & Griya Pijat & 59 & 13 & Gelanggang Renang & 3 \\
5 & Bioskop & 58 & 14 & Tunggangan Anak-anak & 2 \\
6 & Bilyard & 49 & 15 & Mandi Uap & 1 \\
7 & Balai Pertemuan & 33 & 16 & Padang Golf & 1 \\
8 & Diskotik & 32 & 17 & Pusat Olah Raga & 1 \\
9 & Dingdong & 26 & & & \\
\hline
\end{tabular}

Sumber: Suku Dinas Pariwisata Jakarta Selatan

Jika dilihat dari tabel di atas, maka jumlah jenis usaha terbanyak di bidang rekreasi dan hiburan adalah musik hidup, diikuti oleh karaoke dan salon, dan yang terkecil adalah mandi uap, padang golf, serta pusat olah raga. Sebaran jumlah dan jenis usaha rekreasi dan hiburan per Kecamatan, dapat dilihat pada Tabel 5 berikut:

Tabel 5 Jumlah dan Jenis Usaha Rekreasi dan Hiburan per Kecamatan

\begin{tabular}{lccccc}
\hline \multicolumn{1}{c}{ Jenis Usaha } & Pancoran & $\begin{array}{c}\text { Pasar } \\
\text { Minggu }\end{array}$ & Cilandak & Jagakarsa & Pesanggrahan \\
\hline Musik Hidup & 1 & 1 & 6 & 0 & 0 \\
Karaoke & 0 & 0 & 4 & 0 & 0 \\
Taman rekreasi & 1 & 0 & 1 & 0 & 0 \\
Griya Pijat & 0 & 3 & 9 & 0 & 1 \\
Bilyard & 8 & 3 & 3 & 4 & 1 \\
Dingdong & 1 & 3 & 2 & 0 & 0 \\
Bioskop & 4 & 4 & 4 & 0 & 0 \\
Diskotik & 0 & 2 & 0 & 0 & 0 \\
Balai Pertemuan & 4 & 3 & 1 & 0 & 0 \\
Pusat Olah Raga & 0 & 0 & 0 & 0 & 0 \\
Gelanggang Renang & 0 & 0 & 0 & 0 & 0 \\
Arena Latihan Golf & 1 & 0 & 1 & 0 & 0 \\
Padang Golf & 0 & 0 & 0 & 0 & 0 \\
Bowling & 0 & 0 & 0 & 0 & 0 \\
Mandi Uap & 0 & 0 & 0 & 0 & 0 \\
Tunggangan Anak2 & 0 & 0 & 0 & 0 & 2 \\
Salon & $\mathbf{2 1}$ & $\mathbf{2 0}$ & $\mathbf{4 2}$ & 0 & $\mathbf{4}$ \\
\hline Jumlah & $\mathbf{4 . 0 9}$ & $\mathbf{8 . 1 7}$ & $\mathbf{0 . 7 8}$ & $\mathbf{0 . 7 8}$ \\
\hline Persentasi & & & & & \\
\hline
\end{tabular}

Sumber: Suku Dinas Pariwisata Jakarta Selatan

Dari tabel di atas, terlihat bahwa jumlah usaha musik hidup dan karaoke terbanyak ada di Kecamatan Kebayoran Baru. Beberapa jenis usaha juga belum tergarap dan tersebar di setiap Kecamatan di Jakarta Selatan, di antaranya adalah taman rekreasi keluarga, pusat olah raga, gelanggang renang, arena latihan golf, padang golf, bowling, mandi uap, dan tunggangan anak-anak. Untuk industri restoran, jenis usaha yang paling banyak dikembangkan dalam bentuk rumah makan dan sebagian terbesar berada di Kecamatan Kebayoran Baru. Data jumlah dan jenis usaha industri Restoran dapat dilihat pada tabel 6 berikut: 
Tabel 6 Jumlah dan Jenis Usaha Industri Restoran per Kecamatan

\begin{tabular}{|c|c|c|c|c|c|}
\hline Jenis Usaha & $\begin{array}{c}\text { Kebayoran } \\
\text { Baru }\end{array}$ & $\begin{array}{c}\text { Kebayoran } \\
\text { Lama }\end{array}$ & Setiabudi & $\begin{array}{l}\text { Mampang } \\
\text { Prapatan }\end{array}$ & Tebet \\
\hline Rumah Makan & 20 & 12 & 5 & 6 & 3 \\
\hline Foodcourt & 3 & 1 & 4 & 1 & 3 \\
\hline Taman rekreasi & 2 & 6 & 6 & 2 & 1 \\
\hline Bakery & 3 & 2 & 5 & 1 & 2 \\
\hline Katering & 2 & 3 & 4 & 3 & 3 \\
\hline Kantin & 3 & 6 & 2 & 5 & 2 \\
\hline $\begin{array}{c}\text { Jumlah } \\
\end{array}$ & 33 & 30 & 26 & 18 & 14 \\
\hline Persentase (\%) & 21.9 & 18.98 & 15.33 & 8.76 & 5.11 \\
\hline Jenis Usaha & Pancoran & $\begin{array}{l}\text { Pasar } \\
\text { Minggu }\end{array}$ & ndak & karsa & Iggrahan \\
\hline Rumah Makan & 3 & 3 & 7 & O & 3 \\
\hline Foodcourt & 3 & 1 & 8 & 0 & 2 \\
\hline Taman rekreasi & 2 & 2 & 3 & כ & 1 \\
\hline Bakery & 2 & 3 & 6 & כ & 3 \\
\hline Katering & 3 & 3 & 2 & 0 & 2 \\
\hline Kantin & 3 & 1 & 2 & 0 & 2 \\
\hline Jumlah & 16 & 13 & 8 & 0 & 13 \\
\hline$\%$ & 5.84 & 2.92 & .44 & 0 & 0.73 \\
\hline
\end{tabular}

Sumber: Suku Dinas Pariwisata Jakarta Selatan

\section{Analisis Peluang Usaha Industri Pariwisata di Jakarta Selatan yang Berpotensi untuk Dikembangkan}

Wilayah Jakarta Selatan memiliki 10 kecamatan, dengan berbagai potensi yang berbeda di tiap daerahnya. Prediksi potensi pertumbuhan industri pariwisata di Jakarta Selatan periode 2009-2014 dapat dilihat pada Tabel 7 berikut:

Tabel 7 Prediksi Potensi Pertumbuhan Industri Pariwisata di Jakarta Selatan

\begin{tabular}{|c|c|c|c|c|}
\hline No & Kecamatan & Hotel & Restoran & $\begin{array}{c}\text { Rekreasi } \\
\text { \& Hiburan }\end{array}$ \\
\hline 1 & Kebayoran Baru & 8 & 54 & 40 \\
\hline 2 & Kebayoran Lama & 2 & 66 & 30 \\
\hline 3 & Setiabudi & 10 & 53 & 35 \\
\hline 4 & Mampang Prapatan & 5 & 61 & 50 \\
\hline 5 & Tebet & 4 & 29 & 33 \\
\hline 6 & Pancoran & 6 & 52 & 31 \\
\hline 7 & Pasar Minggu & 7 & 44 & 28 \\
\hline 8 & Cilandak & 6 & 81 & 54 \\
\hline 9 & Jagakarsa & 2 & 54 & 15 \\
\hline \multirow[t]{3}{*}{10} & Pesanggrahan & 4 & 56 & 15 \\
\hline & Total (unit) & 54 & 550 & 331 \\
\hline & Total (\%) & 5.77 & 58.82 & 35.4 \\
\hline
\end{tabular}

Sumber: Suku Dinas Pariwisata Jakarta Selatan 
Industri Pariwisata apa saja yang masih berpotensi, dapat dilihat dengan memperhatikan struktur kota serta potensi pariwisata di dalamnya. Berikut ini adalah data potensi pariwisata per kecamatan yang ada di Jakarta Selatan.

Tabel 8 Potensi Industri Pariwisata di Jakarta Selatan

\begin{tabular}{lcccccc}
\hline \multirow{2}{*}{ Kecamatan } & \multicolumn{3}{c}{ Jumlah Potensi Industri } & \multicolumn{2}{c}{ Jumlah Industri yang Ada } \\
\cline { 2 - 7 } & Hotel & Restoran & $\begin{array}{c}\text { Rekreasi } \\
\text { \& Hiburan }\end{array}$ & Hotel & Restoran & $\begin{array}{c}\text { Rekreasi } \\
\text { \& Hiburan }\end{array}$ \\
\hline Kebayoran Baru & 8 & 54 & 40 & 14 & 33 & 229 \\
Kebayoran Lama & 2 & 66 & 30 & 2 & 30 & 60 \\
Setiabudi & 10 & 53 & 35 & 13 & 26 & 70 \\
Mampang Prapatan & 5 & 61 & 50 & 10 & 18 & 39 \\
Tebet & 4 & 29 & 33 & 4 & 14 & 25 \\
Pancoran & 6 & 52 & 31 & 1 & 16 & 21 \\
Pasar Minggu & 7 & 44 & 28 & 3 & 13 & 20 \\
Cilandak & 6 & 81 & 54 & 8 & 38 & 42 \\
Jagakarsa & 2 & 54 & 15 & 0 & 0 & 4 \\
Pesanggrahan & 4 & 56 & 15 & 4 & 13 & 4 \\
\hline
\end{tabular}

Sumber: Suku Dinas Pariwisata Jakarta Selatan

Di Kecamatan Kebayoran, industri perhotelan untuk jenis kelas hotel berbintang masih memungkinkan untuk bisa dimasuki, demikian juga halnya dengan restoran. Untuk rekreasi dan hiburan, yang masih menarik adalah usaha taman rekreasi dan keluarga, musik hidup, mandi uap, diskotik, dan bilyar, sedangkan karaoke sudah mengalami kejenuhan. Wilayah Kebayoran Lama untuk industri perhotelan sudah sangat terbatas untuk dimasuki karena wilayah ini diperuntukkan untuk daerah pemukiman dan resapan air. Berbeda halnya dengan industri restoran, semua jenis usaha restoran masih memungkinkan untuk bisa dimasuki. Pada industri rekreasi dan hiburan, usaha yang masih menarik adalah musik hidup, gelanggang renang, balai pertemuan, salon, bilyard, dan dingdong, sedangkan usaha griya pijat sudah mengalami kejenuhan.

Industri perhotelan di Kecamatan Setiabudi untuk semua jenis kelas hotel berbintang masih memungkinkan untuk bisa dimasuki, demikian juga halnya dengan restoran. Pada industri rekreasi dan hiburan, usaha yang masih menarik untuk dimasuki adalah karaoke, griya pijat, bilyard, bioskop, diskotik, dan salon, sedangkan yang sudah mengalami kejenuhan adalah musik hidup. Di Kecamatan Mampang Prapatan, semua jenis kelas hotel berbintang masih memungkinkan untuk dimasuki, demikian juga dengan industri restoran. Untuk industri rekreasi dan hiburan, yang masih menarik adalah karaoke, dan salon. Sedangkan musik hidup sudah mengalami kejenuhan. Di Kecamatan Tebet, tidak semua industri bisa dimasuki karena terbatasnya lahan dan karena Kecamatan Tebet diperuntukkan untuk daerah pemukiman dan resapan air. Untuk industri restoran, masih terbuka dan memungkinkan untuk bisa dimasuki.

Di Kecamatan Pancoran, juga tidak semua industri bisa dimasuki karena sebagian wilayahnya diperuntukkan untuk daerah pemukiman dan resapan air, sedangkan sebagian lagi diperuntukkan untuk usaha dan perdagangan. Industri perhotelan di Kecamatan Pasar Minggu untuk semua jenis kelas hotel berbintang masih memungkinkan untuk bisa dimasuki, demikian juga untuk restoran. Untuk rekreasi dan hiburan, yang masih menarik adalah usaha griya pijat dan salon. Di kecamatan semua jenis kelas hotel berbintang dan restoran masih memungkinkan untuk bisa dimasuki. Di industri rekreasi dan hiburan, yang masih menarik adalah usaha musik hidup, karaoke, griya pijat, dan bilyar. Di Kecamatan Jagakarsa dan pesanggrahan, tidak semua industri bisa dimasuki karena terbatasnya lahan dan diperuntukkan untuk daerah pemukiman dan resapan air. 


\section{Usulan Rekomendasi}

Perkembangan pariwisata telah menjadi fenomena global, baik dalam tatanan persaingan bisnis dan perdagangan, maupun yang menyangkut aspek-aspek sosial budaya, lingkungan hidup serta diplomasi antar bangsa dan negara. Perubahan strukturisasi ekonomi dunia serta pesatnya perkembangan teknologi informasi dan transportasi berpengaruh terhadap kepariwisataan dalam merebut peluang pasar, nilai manfaat dan nilai daya tarik, dengan strategi promosi yang terukur dan tepat sasaran.

Tantangan dalam pembangunan di sektor pariwisata adalah menerapkan konsep ”sustainable tourism", yang sekaligus menjadikan sektor ini andalan dalam meningkatkan Penerimaan Asli Daerah (PAD). Sejalan dengan dinamika pembangunan, tuntutan reformasi mensyaratkan bahwa pentingnya orientasi dan fokus perencanaan dan pembangunan pariwisata dalam rangka pencapaian good goverment, sustainable tourism development, service culture, etika, dan perlindungan hak asasi. Wilayah Jakarta Selatan merupakan salah satu wilayah di Provinsi DKI Jakarta yang memiliki potensi untuk menarik investor menanamkan modalnya di sektor pariwisata, yang nantinya dapat mewujudkan Jakarta Selatan sebagai destinasi pariwisata yang pada gilirannya akan meningkatkan PAD.

Dari 10 kecamatan yang ada di wilayah Jakarta Selatan, terdapat 4 kecamatan yang memiliki peluang untuk menarik investor menanamkan modalnya di sektor pariwisata antara lain, yaitu (1) Kecamatan Setiabudi, peluang investasi lebih condong dimasuki oleh industri perhotelan karena kecamatan ini merupakan daerah elit dan pusat perkantoran; (2) Kecamatan Mampang Prapatan peluang investasi lebih condong dimasuki oleh industri restoran karena di Kecamatan Mampang Prapatan terdapat kawasan Kemang yang banyak dihuni oleh warga asing dan banyak diminati oleh warga asing sebagai tempat wisata kuliner. Lokasinya yang strategis memungkinkan pengunjung dari berbagai arah mendatangi kawasan ini; (3) Kecamatan Pasar Minggu akan dikembangkan oleh Pemerintah Kota Administrasi Jakarta Selatan menjadi daerah bisnis sehingga nantinya akan menjadi destinasi kuliner, rekreasi dan hiburan; dan (4) Kecamatan Kebayoran Baru sebagian besar daerahnya merupakan daerah pemukiman yang dikelilingi oleh daerah pertokoan dan pusat bisnis sehingga peluang untuk berinvestasi pada sektor industri rekreasi dan hiburan sangat besar pada daerah ini.

\section{SIMPULAN}

Berdasarkan penelitian yang berjudul "Peluang Usaha Industri Pariwisata di Jakarta Selatan", maka dapat ditarik simpulan, yaitu (1) Tahun 2008 di wilayah Jakarta Selatan tercatat ada 774 usaha pariwisata yang beroperasi di Jakarta Selatan. 66\% di antaranya adalah usaha rekreasi dan hiburan, $27 \%$ nya adalah usaha restoran/rumah makan, dan sisanya adalah hotel; (2) Wilayah Jakarta Selatan dengan potensi yang dimilikinya dapat dikembangkan sebagai destinasi pariwisata dengan berbagai usaha pariwisata yang berpeluang besar; dan (3) Usaha di industri rekreasi dan hiburan serta perhotelan sangat potensial untuk dikembangkan di wilayah Jakarta Selatan. 


\section{DAFTAR PUSTAKA}

Anonim. (2008). Kota Madya Jakarta Selatan. Diakses dari www.selatan.jakarta.go.id/web2008.

Chandra, W.W., and Hendro. (2006). Smart and good entrepreneur, Candle Luhur Abadi.

Harmaizar, Z. (2006). Mengenali potensi wirausaha entrepreneur dan intrapreneur, Jakarta: CV Dian Anugerah Prakasa.

Hendro. (2005). How to become a smart entrepreneur and to start a new business, Yogyakarta: ANDI Offset.

Hendry, F. (2006). Prinsip-prinsip manajemen, Jakarta: Erlangga.

Indriantoro, N., dan Supomo, B. (2002). Metodologi penelitian dan bisnis untuk akuntansi dan manajemen, edisi pertama, Yogyakarta: BPFE.

Robbins, S.P., dan Mary, C. (2002). Manajemen, edisi ketujuh, Jakarta: PT Indojaya Multitama.

Sugiyono. (2004). Metode penelitian bisnis, Bandung: CV AlfaBeta.

Supranto. (2004). Statistik: Teori dan aplikasi, Jakarta: Erlangga.

Universitas Bina Nusantara, Jakarta. The Winners Journal, Vol.08, No.2, September 2007, Jakarta.

Zimmerer, T.W., Scarborough, N.M., and Wilson, D. (2008). Essentials of entrepreneurship and small business management. 